\title{
The Cultural Reconstruction Of Taboo Under Mama Uluk's Leadership In Kampong Dukuh, A Sundanese Traditional Hamlet In Garut Regency West Java Indonesia
}

\author{
Ai Juju R., Wanda Listiani, Irma Rachminingsih \\ Sekolah Tinggi Seni Indonesia (STSI) Bandung \\ Jl. Buahbatu 212 Bandung 40265
}

\begin{abstract}
ABSTRAK
Kampung Dukuh yang terletak di Desa Ciroyom, Kecamatan Cikelet Kabupaten Garut merupakan salah satu kampung adat yang ada di Jawa Barat yang memiliki banyak keunikan. Pamali sebagai salah satu sistem pengetahuan masyarakat adat Sunda. Pamali masih dipertahankan dalam kebudayaan masyarakat adat Kampung Dukuh. Walaupun tidak ada resiko yang tertulis ketika melakukan hal yang melanggar pamali, namun masyarakat kampung adat masih merasa takut durhaka atau dosa jika pamali tidak dilaksanakan dalam keseharian hidupnya. Sekaitan dengan hal ini, penelitian ini bertujuan menggambarkan berbagai larangan atau pamali yang telah direkonstruksi di masa kepemimpinan Mama Uluk di kampung Adat Dukuh Kabupaten Garut. Penelitian ini menggunakan metode kualitatif dengan teknik pengumpulan data wawancara dan pengamatan langsung. Hasil penelitian ini menjelaskan cara penyampaian larangan pada waktu yang telah ditentukan dan jenis larangan atau pamali atau pamali yang dipelihara dan terus diwariskankan secara turun temurun sampai saat ini dalam kehidupan sehari-hari seperti larangan di Makom Syech Jalil, Hutan Lindung dan bagaimana ketua adat (mama uluk) dalam kepemimpinannya merekonstruksi budaya tersebut dalam kehidupan keseharian mereka di kampung Dukuh kabupaten Garut.
\end{abstract}

Kata kunci: rekonstruksi budaya, mama uluk, kampung Dukuh, masyarakat adat

\begin{abstract}
Kampong Dukuh located in Ciroyom Village, Cikelet District, Garut Regency is one of traditional hamlets in West Java Province having many unique features. Pamali (taboo prohibition) as Sundanese peoples' body of knowledge is still maintained in the traditions of kampong Dukuh. Although there is no written sanction for someone who violates pamali, members of traditional hamlet community are still afraid of being faithless or sinful if they do not comply with the cultural prohibitions in their daily activities. Thus, this research is aimed at describing some cultural prohibitions or pamali which have been reconstructed under Mama Uluk's leadership in kampung Dukuh in Garut Regency. This research used qualitative method with interview and observation as data collection techniques. The result shows ways of delivering prohibitions at certain time and categories of prohibition or pamali maintained nowadays and has been passed down from generation to generation, such as prohibition of Syech Jalil's grave and Protected Forest. It also describes how the customary or traditional leader (Mama Uluk) under his leadership reconstructs the traditions of Kampong Dukuh in Garut regency.
\end{abstract}

Keywords: cultural reconstruction, Mama Uluk, kampong Dukuh, traditional hamlet community 


\section{INTRODUCTION}

Cadu kaalaman deui nepi ka tujuh turunan means never happened again to my descendants until the seventh. Traditional Sundanese people believe in the consequences of violating the prohibitions. Forbear or forbearance is prohibition. There is also another term, taboo. Taboo is different from prohibition in a sense that a violation of a taboo causes the violator calamity, whereas an offense of a prohibition causes the offender physical or social sanctions. Taboo (Laksana, 2009: 17-18) is forbiddance or something forbidden. The term taboo is of Polynesian original from the words "tabu" or "tapu", taboo (Fershtman, 2011: 139 ) is defined as the prohibition of an action based on the belief that such behavior is either too sacred and consecrated or too dangerous and accursed for ordinary individuals to undertake. Taboo (Ogunyemi, 2007: 4) are for the most part irrational and hard to defend on practical or humanitarian ground, and lawas, whose function in providing equal and justifiable protection for all members of society is one of the acknowledged hallmarks of civilized society. Taboo in kampong Kanekes, for example, can be classified into three categories. Firstly, taboo to protect the purity of human's soul; secondly, taboo to protect the purity of mandala; and thirdly, taboo to protect tradition. Taboo is carried out and can be seen from a sanction or a punishment given to a taboo offender.

Taboo, according to Wundt (Freud, 2001: $22)$, is the oldest unwritten code of law of humanity. Different types of taboos are (a) natural or direct, the result of mana (mysterious power) inherent in a person or thing; (b) communicated or indirect, equal with the result of mana acquired or imposed by a priest, chief or other person; (c) intermediate because of various other factors, exclude taboos such as religious prohibition. Taboo in West Java traditional community is known by the term pamali.

Pamali as one of traditional Sundanese body of knowledge is still maintained in the tradition of indigenous Sundanese people. Indigenous people are people who live according to their traditional values and customary way of life which have been passed down from generation to generation (Pramaputra, 2008: 7). Pamali provides insights and meanings for these people. Although there is no written sanction for a violation of pamali, the members of traditional community are still afraid of being faithless or sinful if their deeds do not comply with pamali. Pamali is more than a myth preserved. It is a
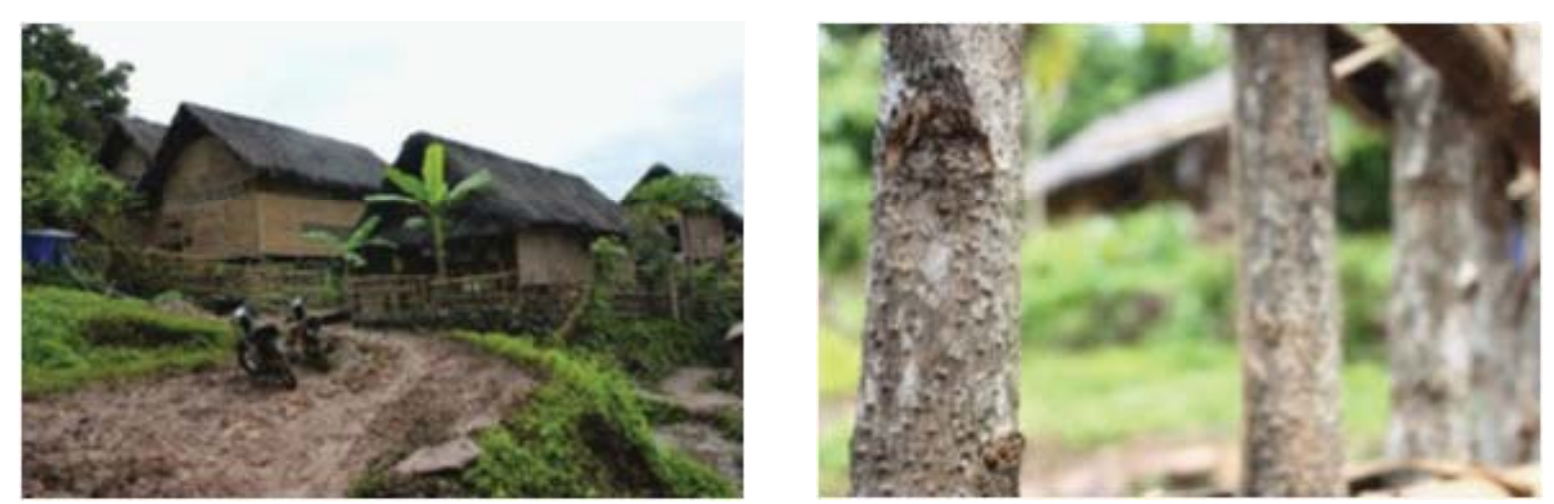

Figure 1

The wooden fence separating inner and outer kampong Dukuh Source: Private collection, 2013 

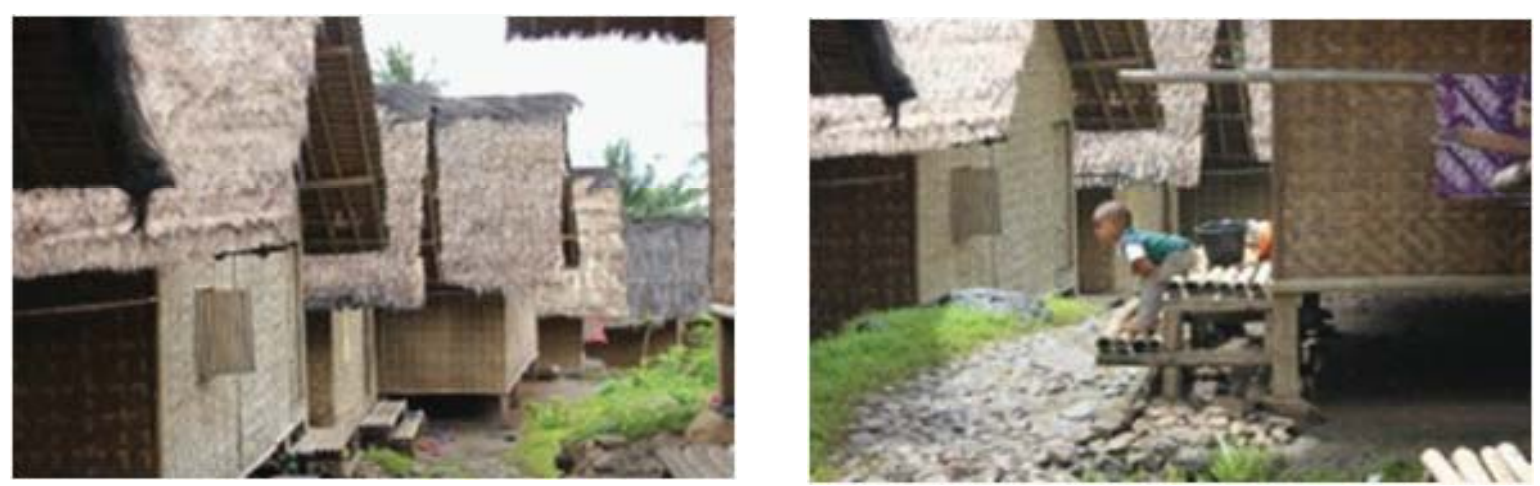

Figure 2

Kampong Inner Dukuh

Source: Private collection, 2013

belief they hold from generation to generation. Preference, belief and norm shape human behavior a s the result of genetic evolution and parts of pamali inheritance from ancestors and acquired from learning and social interaction.

Pamali is maintained from generation to generation in Sundanese traditional community, especially in kampong Dukuh community of Garut Regency. The underlying cause of pamali provides logical reasons for environmental protection as to prevent natural disasters. On the other hand, pamali as cultural expression guards Sundanese traditions off globalization impacts and foreign influence. The fading understanding of pamali in present context has indirectly diminished the identity of Sundanese tra- ditional community. Yet, such condition is different from that of kampong Dukuh in Garut Regency that carries on reconstructing the taboo traditions under the Mama Uluk's leadership.

\section{METHOD}

This research used qualitative method with interview and observation as data collection techniques. This research explores the taboo prohibition or pamali maintained nowadays and has been passed down from generation to generation, such as prohibition of Syech Jalil's grave and Protected Forest. It also describes how the customary or traditional leader (Mama Uluk) under
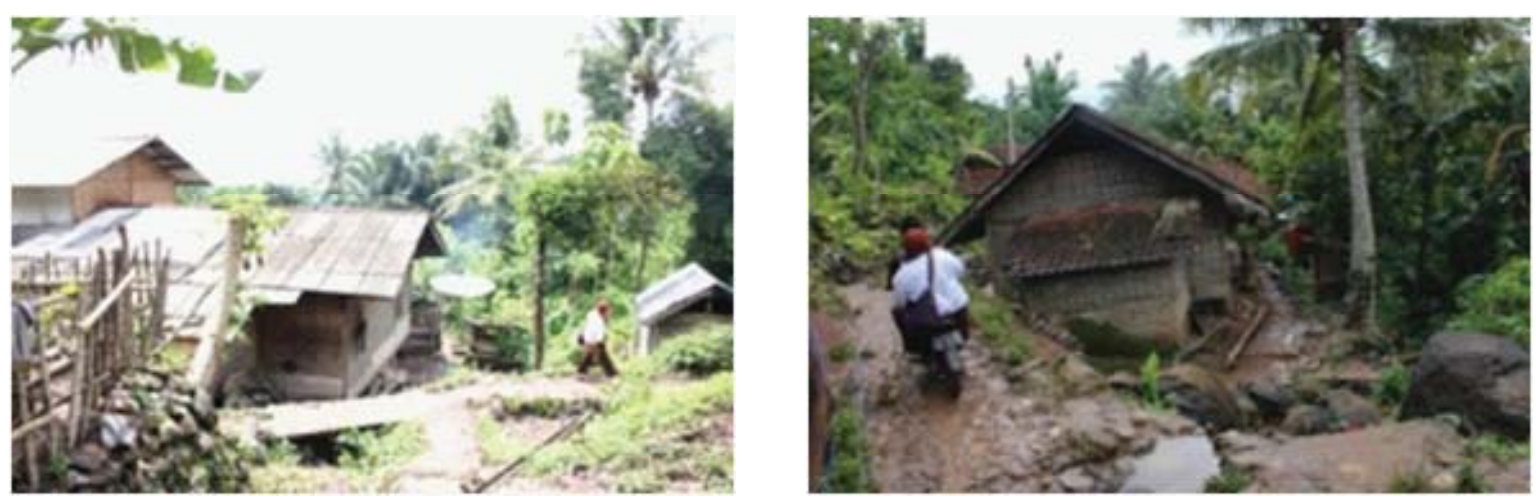

Figure 3

Kampong outer Dukuh

Source: private collection, 2013 

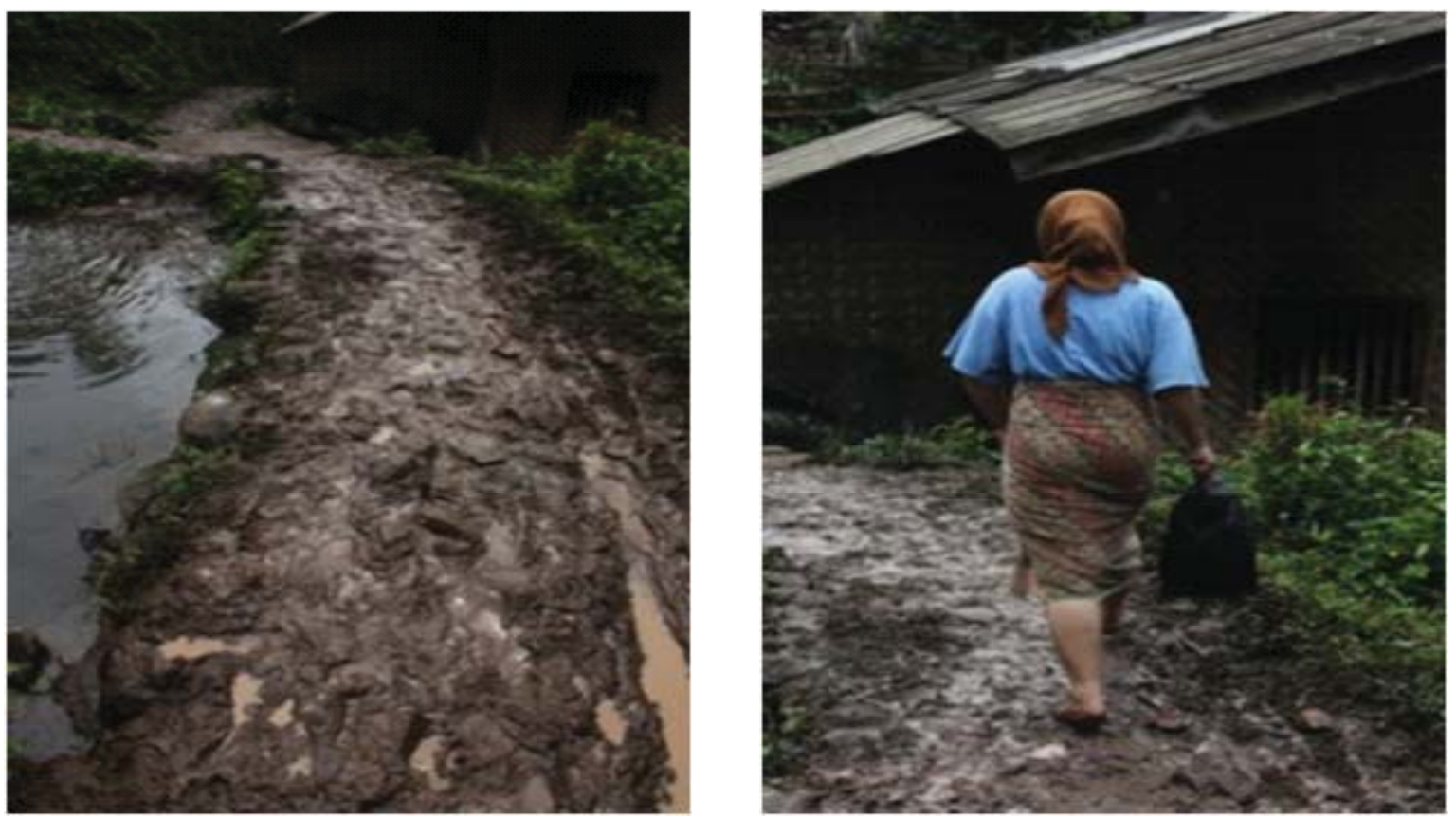

Figure 4

Road to Kampong Inner Dukuh

Source: Private collection, 2013

his leadership reconstructs the traditions of Kampong Dukuh in Garut regency.

\section{RESULT AND DISCUSSION}

Kampong Dukuh located in Ciroyom Village, Cikelet District, Garut Regency is one of Sundanese traditional villages in West Java Province that has many unique features. Dukuh community is an open community that keeps in touch with other communities outside its village. Kampong Dukuh community is divided by areas into inner and outer Dukuh, separated from each other by natural wooden fence. This wooden fence shows that they are open to and live in harmony with outsiders.

The settlements in kampong Dukuh have always been consisting of 40 houses and other three structures that function as (1) mosque, (2) Islamic school and gathering place for Islamic discussion, (3) a small house dedicated for chanting in praise of
Allah. The three structures built closed to tribe leader's house, Mama Uluk. The number of houses is constant from time to time. What follows is the condition of kampong inner Dukuh and kampong outer Dukuh:

The houses at kampong inner Dukuh are identical in terms of shape, building materials, window model, and unfurnished interior. The kampong inner Dukuh people use traditional eating utensils, such as coconut-shell drinking glass and banana-leaf plate. Yet, they serve food for guests on zinc or aluminum plates. Their houses that have no partition walls show their simple way of life and tradition preservation. This condition is quite different from that of kampong outer Dukuh which has adapted to the era development. The houses in kampong outer Dukuh are made of brick wall with glass windows. The kampong outer Dukuh people also use electronic devices such as parabola antenna, hand-phone, television, and radio.

The condition of kampong of outer Du- 


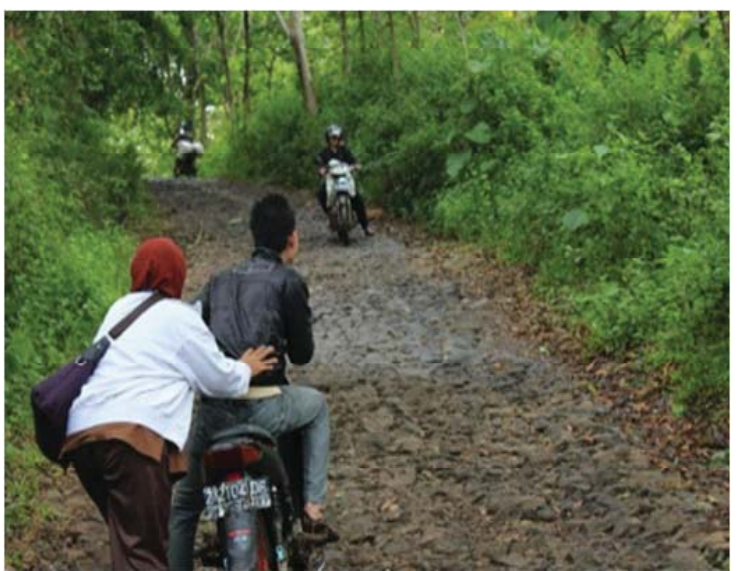

Figure 5

Access to traditional kampong Dukuh Source: Private collection, 2013

kuh is different from that of kampong of inner Dukuh whose community still obeys Mama Uluk's order such as a taboo of using footwear to walk into kampong of inner Dukuh like the woman in the following picture. The leadership in kampong Dukuh is so different from formal leadership concept that the obedience of kampong Dukuh community to Mama Uluk is stronger. This can be seen from the community's obedience toward all taboos in traditional kampong of inner Dukuh.
Wet and slippery dirt road is unsafe to be walked on by members of kampong Dukuh community who use footwear. It is common that the outsiders who wear sandals or shoes will slip on the slippery road if they are not careful. Kampong Dukuh is difficult to be reached by public transports because of the rough condition of the road. Kampong Dukuh is 7 kilo-meters away from the main road. An outsider generally will take a motorcycle taxi to get to Dukuh hamlet. Its fare may range from $\operatorname{Rp} 60,000$ to $\operatorname{Rp} 100,000$. Despite this difficult access, visitors keep coming to kampong Dukuh. Likewise, this condition does not hamper any member of Dukuh community who wants to go to the city to fulfill his or her daily needs. Peoples of inner Dukuh persist to obey all prohibitions passed down from generation to generation, as mentioned by Mama Uluk. Children from Dukuh traditional village acquire education by studying at Islamic boarding schools in Cirebon, Banten and Java. The following is the figure of access to traditional kampong Dukuh:

According to Mama Uluk's account as the tribe leader of kampong of inner Dukuh, old kampong Dukuh was built by an
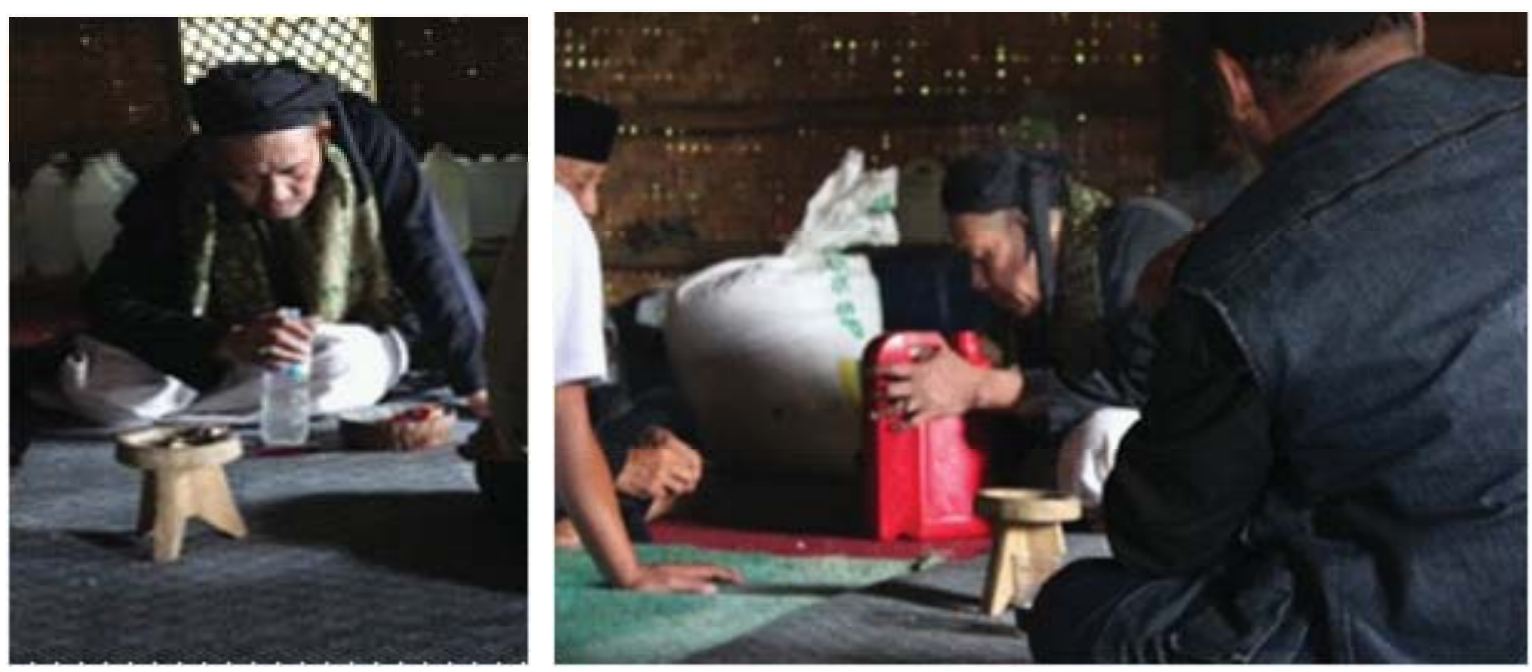

Figure 6

Mama Uluk

Source: Private Collection, 2013 

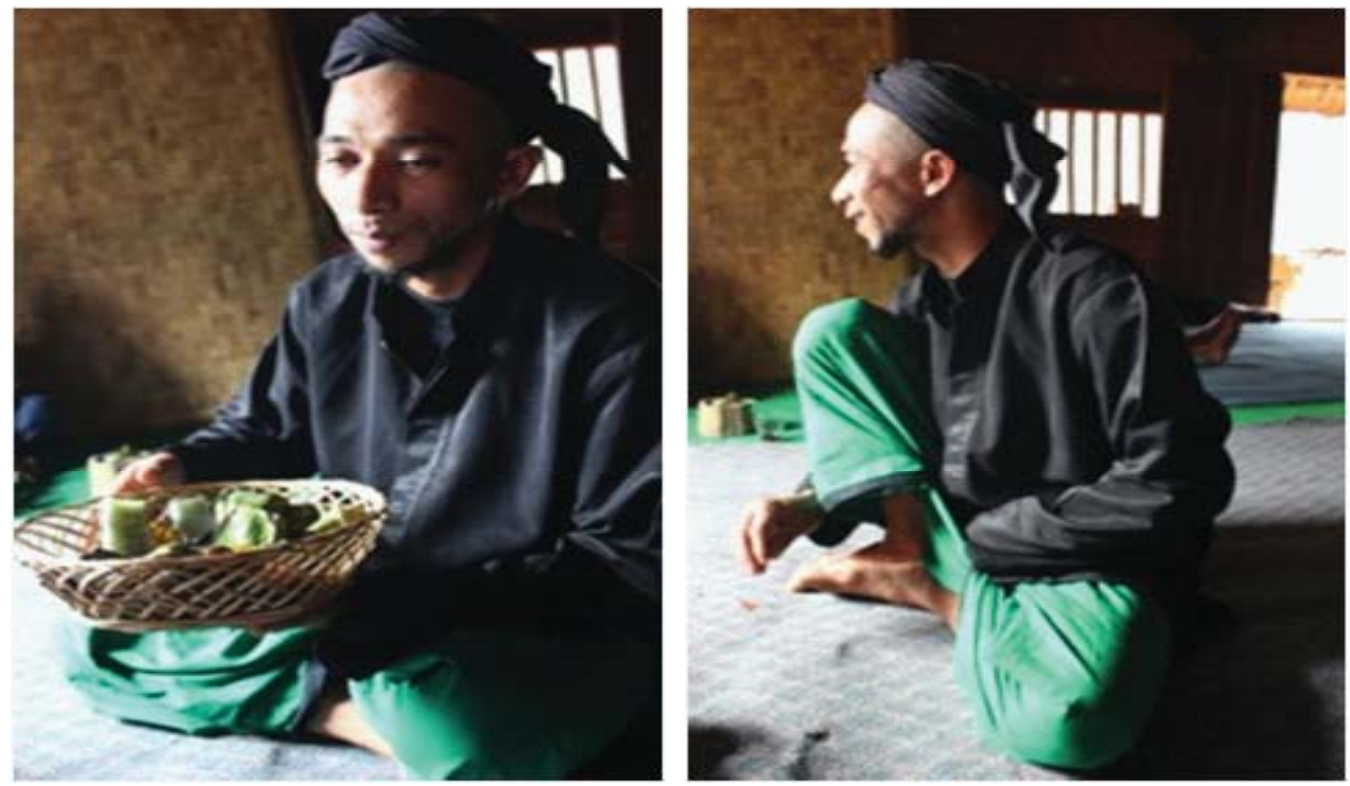

Figure 7

Prohibitions of eating and sitting position

Source: Private document, 2013

Imam named Sheikh Jalil whose leadership had been passed on to his heirs. Nowadays Mama Uluk as both the descendant of Sheikh Jalil and the tribe leader preserves all aspects of life and harmony of Dukuh community.

Peoples of traditional kampong Dukuh consist of the descendants of Sheikh Jalil and the migrants. Yet, any migrant who wants to settle in kampong of inner Dukuh should ask permission from Mama Uluk. Mama Uluk as the tribe leader then performs a particular ritual with zikir (remembrance) to get sign as to whether or not he or she is allowed to settle. If there is a sign, he or she is allowed to settle and must conform to the rules of traditional kampong of inner Dukuh, as been ordered by Mama Uluk.

Prohibitions in Dukuh traditional hamlet have been kept alive and passed down to generation of the present-era. In addition to living a simple life, peoples of $\mathrm{Du}$ kuh traditional hamlet must conform to the three categories of prohibition in the rule of Mama Uluk, namely:

\section{a. Prohibitions of daily life}

Prohibitions of daily life include firstly, a house should not use brick walls. Its roof should be made from thatch and its interior should be unfurnished; Secondly, all doors should face West and the shape of window and roof should be identical. Thirdly, one should not eat crackers and cucumber by using left and right hands simultaneously. Fourthly, one should not drink while standing. Fifthly, one should not sit with his or her legs stretched out facing west or direction of Syech Jalil's grave. Fifthly, while eating rice, one should neither lift his or her rice bowl nor bend his or her legs. Seventhly, the visitors to traditional kampong Dukuh should not bring any water from outside the village; every person who comes to and stays in Dukuh hamlet should only use the sacred water available in traditional kampong Dukuh.

\section{b. Prohibitions of Syech Jalil's grave}

Prohibitions of Syech Jalil's grave cover firstly, visiting Syech Jalil's grave should be done in group and led by Mama Uluk 

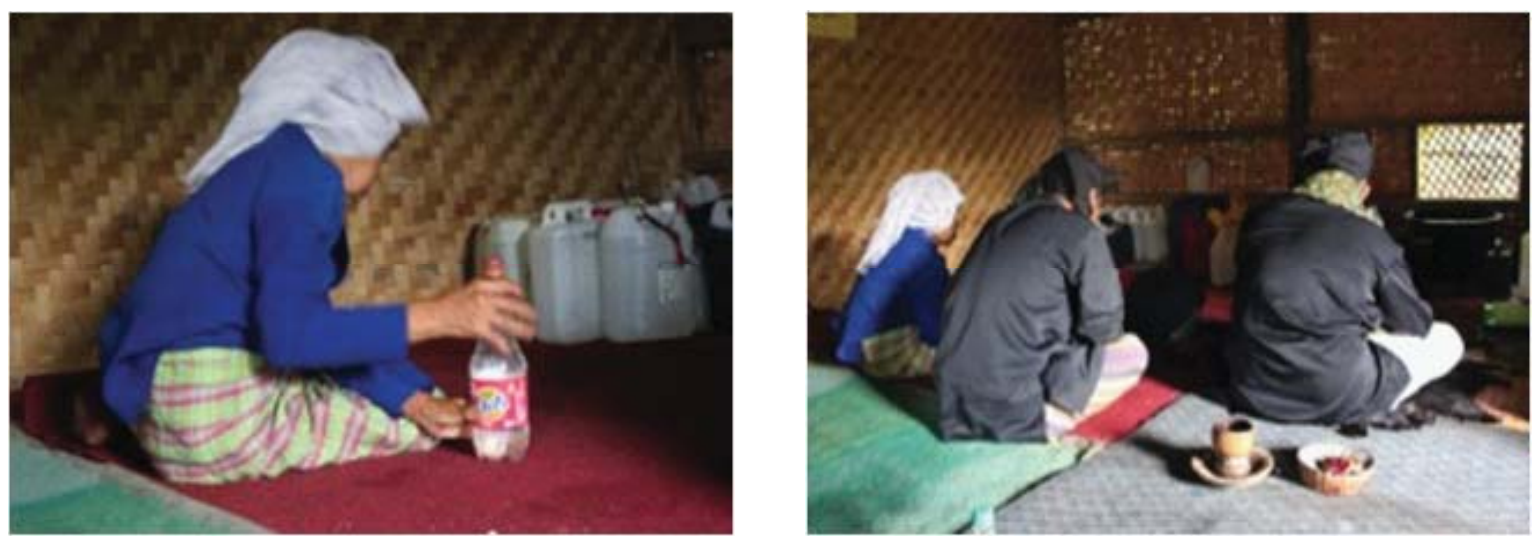

Figure 8

Holy water (prayer-contained water) Source: Private document, 2013

on Saturday only. Secondly, a civil servant should not walk into the area of Syech Jalil's grave. Thirdly, every visitor to Syech Jalil's grave should be clean and free of impurities. Fourthly, one should not spit around the area of Syech Jalil's grave. Fifthly, a visitor should walk barefoot to Syech Jalil's grave. Sixthly, women's area is separated from men's area. Seventhly, a male visitor should wear plain clothes, without any motif or decoration, and no underwear. It is recommended that he dresses in black. Eighthly, a female visitor should wear a kebaya (a Sundanese traditional blouse-dress) and an undecorated plain sarong usually worn by male with no panty and bra. Ninthly, a newly engaged couple is forbidden to walk into the area of Syech Jalil's grave. Tenthly, any member of Dukuh community visiting Syech Jalil's grave should wear black clothes, sarong and headband.

\section{c. Prohibitions of the protected forest}

Prohibitions related to the protected forest are first, anyone from inside or outside traditional kampong Dukuh should not take, cut or burn anything in the protected forest. Second, everyone should not disturb the sacred spring. The spring water is only allowed to be taken from the catchment for daily use. Dukuh hamlet's water is believed to be derived from Makkah (that became the spring) as a source of life for community of inner Dukuh hamlet. The following is the picture of holy water (prayer-contained water) usually requested by members of Dukuh hamlet community and visitors:

The visitors having social problems (unemployment, debt, soil fertility, family conflict, position of rank, etc) came to kampong Dukuh for Mama Uluk's holy water. Visitors asking for the holy water gave some money voluntarily. They were offered to take potluck when visiting Mama Uluk's house. On Saturday they went to Syech Jalil's grave with Mama Uluk.

\section{CONCLUSIONS}

Besides the three categories of prohibitions mentioned above, there are also gatherings of Islamic discussion held every Tuesday, Friday and Saturday in traditional kampong Dukuh. The life of inner Dukuh peoples is full of religious atmosphere with Mama Uluk as its role model. Mama Uluk's position as the role model can be seen from the sermon delivered by Mama Uluk and the holy water (prayer-contained water) requested by some villagers and visitors whenever they have problems. 


\section{References}

Freud, Sigmund

2001 Totem and Taboo. London: Routledge

Fershtman, Chaim, Uri Gneezy and Moshe Hoffman

2011 “Taboos and Identity: Considering the Unthinkable", American Econo mic Journal: Microeconomics 3 (May 2011), p. 139-164

I Ketut Darma Laksana

2009 Tabu Bahasa: Salah Satu Cara Memahami Kebudayaan Bali. Bali: Udayana University Press
Ogunyemi, Olatunji

2007 “The Implications of Taboos Among African Diasporas for the African Press in the United Kingdom", journal of Black Studies, Vol X No. X, Sage Publications

Pramaputra

2008 Buku Pedoman Pelestarian dan Pengembangan Desa Budaya Jawa Barat. Bandung: Balai Pengelolaan Kepurbakalaan, Sejarah dan Nilai Tradisional Dinas Kebudayaan dan Pariwisata Provinsi Jawa Barat

Interview Script, Mama Uluk, Desember 2013 